\title{
The Innovative Potential of Digital Transformation of the Russian Higher Education System: Trends of the Competence Approach
}

\author{
Anna Vetkina \\ Institute of Economics \\ and Management \\ Yaroslav-the-Wise \\ Novgorod State \\ University (NovSU) \\ Veliky Novgorod, Russia \\ anna.vetkina@novsu.ru
}

\author{
Tatyana Kudryashova \\ Institute of Economics \\ and Management \\ Yaroslav-the-Wise \\ Novgorod State \\ University (NovSU) \\ Veliky Novgorod, Russia \\ tatyana.kudryashova@novsu.ru
}

\author{
Oxana Fikhtner \\ Institute of Economics \\ and Management \\ Yaroslav-the-Wise \\ Novgorod State \\ University (NovSU) \\ Veliky Novgorod, Russia \\ oxana.fikhtner@novsu.ru
}

\author{
Vladimir Trifonov \\ Institute of Economics \\ and Management \\ Yaroslav-the-Wise \\ Novgorod State \\ University (NovSU) \\ Veliky Novgorod, Russia \\ tva@novsu.ru \\ Yurga Technological \\ Institute, National \\ Research Tomsk \\ Polytechnic University \\ Tomsk, Russia \\ v.trifonov@rambler.ru
}

\author{
Elena Zhukova \\ Institute of Humanities \\ Yaroslav-the-Wise \\ Novgorod State \\ University (NovSU) \\ Veliky Novgorod, Russia \\ elena.zhukova@novsu.ru
}

\begin{abstract}
In the conditions of digital transformation of society, competence-oriented professional education is able to solve the problems of accelerated adaptation of the individual to the complex changes occurring today in the development of socio-economic processes. The digital economy as an absolutely new business model alters the consciousness of a large part of the population, creating conditions for developing and implementing breakthrough technologies, increasing labor productivity and competitiveness of organizations, reducing the consumption of resources, improving the quality of life. Higher education, as one of the forms of reproduction of human capital for the digital economy, will be able to respond to external challenges, only based on innovative approaches to learning. The paradigmatic approach to professional-competence training of an innovative strategy of higher education predetermines the movement from subject-based learning to synergetic pedagogics. The innovative potential of digital transformation of the Russian system of higher education is aimed at the development of an adaptable competent personality. The paper presents an integration model of an adapted competent-developed personality in the system of professional-educational public relations.
\end{abstract}

Keywords-competence-oriented professional education, digital transformation of society, digital economy, innovative higher education strategy, integration model of an adapted competent personality, propaedeutic system of integrated education, convergent approach in higher education, tracks of the educational process.

\section{INTRODUCTION}

The rapidly changing socio-economic conditions, when modern life makes new demands on specialists, will determine in the coming years the trends of innovative changes in the system of higher education. In the information society, the non-material sphere is given a special role of the main productive resource and the main factor of the competitiveness of the new economy.

Competence-oriented professional education solves the problems of accelerated adaptation of the individual to modern life realities, to complex processes of digital transformation of society, both in technological and in psychological terms. Functional information literacy, mobility, professional and psychological readiness for permanent retraining are important for the employee in modern digital economy. Modern digital technologies radically change the economy and the labor market, which requires innovative changes not only in the content of education, but also in its organization.

The concept of modernization of the Russian education is focused on the implementation of a competence approach in education, development of key (basic, universal, etc.) competencies, i.e. readiness of learners to use the acquired knowledge, skills and abilities, and also the methods of activity in life to solve practical and theoretical tasks. Key competencies are proclaimed as the new paradigm of education result. 


\section{LITERATURE REVIEW}

The rapidly changing world, the processes of integration and globalization, greening of the modern economy [1], technological aspects of social development explain the enormous interest and extensive research in the field of education at various hierarchical levels. The processes of organization of educational activities are being studied both at the school level, and at the level of vocational training and higher education $[2,3,4]$.

In the early XXI century, there was an obvious interest in the process of computerization and widespread use of Internet technologies in educational activities. The use of specialized software products, database processing methods, simulation of business processes and much more has become an integral part of the economy and, therefore, could not but be reflected in educational activities $[5,6,7]$.

The processes of interaction between educational technologies and the real sector of the economy have been seriously studied $[8,9,10]$. It became obvious that for the stable development of the economy, powerful regulatory impacts are needed from governments. It led to the development of competencies in entrepreneurship, management, and business administration among graduates of educational institutions $[11,12]$.

Of great interest are research works related to the study of the "knowledge triangle" [13], knowledge management issues [14], the inverted learning model [15], as well as numerous studies examining various paradigms forming in the education system $[16,17,18]$.

Over the years, the focus of researchers' attention is on the development of various types of students' competencies. For example, the TUNING project, which began in 2001, covered a number of countries, including the Russian Federation (TUNING-RUSSIA - 2013), aimed at bringing together educational structures in the Bologna countries specifically through the study and comparison of competencies $[19,20,21,22]$. The body of the accumulated knowledge in this area determined the appearance introduction of a new category in the definitions concerning the organization and implementation of educational activities, namely the competence approach. The complexity and multidimensionality of this category explains the need for the careful study.

\section{RESULTS AND DISCUSSION}

The implementation of the competence approach is a rather complex process that is being formed and modified as knowledge, experience; results of approbation and response to the challenges arising in society accumulate. One such challenge so far is the lack of a unified classification and a common understanding of the content of competencies in education and in the business environment. The approach of the division of the competences acquired in the training specialists into universal, general professional and professional education, which is being formed in Russian education, is the result of the evolutionary process and a serious understanding of the various approaches used in domestic and foreign practice.

Quite complex in this issue was the study and establishment of so-called general cultural competences (now universal) that must be present in each educational program and form the competencies required for the individual, regardless of the scope of his professional activities. It is these competencies that should most fully reflect the willingness of an educated person to operate productively in a modern society.

From 2014 to 2017, Institute of National Projects in conjunction with the "Tuning Center" of the Faculty of Economics of Moscow State University named after M.V. Lomonosov and with the active participation of many Russian universities, including Yaroslav the Wise Novgorod State University (NovSU) conducted a study of the level of development of universal (general cultural) competencies of students on the basis of a model of general cultural competencies based on federal state standards and taking into account the characteristics of competence models used in the business environment. Such models include:

- atlas of the new professions by the Agency for Strategic Initiatives;

- competence models by employers;

- competency model (L. Spencer \& S. Spencer);

- results of the Tuning-Russia project in the field "Economics" [20].

The study was carried out in three waves: spring 2014, autumn 2015, autumn 2016. NovSU among 11 Russian universities took part in all three waves of research.

In all, 2337 students from 27 Russian universities (27 regions of Russia) took part in the third wave of the study, which makes its results indicative and significant.

Important for the interpretation of the results of the study was the fact that separate cohorts of students (in the dynamics of years 1, 3 and 4), as well as the first year students in all three waves of research were studied.

The tools used relied on questionnaires (students' selfassessment of their skills and abilities) and made it possible to assess the level of development of general cultural competencies among students enrolled in the enlarged group "Economics and Management". Each student was offered a questionnaire that included 81 questions.

In the proposed model, general cultural competences were formulated as follows (Table 1).

On the basis of the theoretical model using the method of factor analysis and construction of summation scales, 81 questions were grouped into 53 indicators which form 15 competencies.

TABLE 1 GENERAL CULTURAL COMPETENCIES ACCORDING TO THE MODEL OF THE INSTITUTE OF NATIONAL PROJECTS

\begin{tabular}{|c|l|}
\hline $\begin{array}{c}\text { General cultural } \\
\text { competencies }\end{array}$ & \multicolumn{1}{|c|}{ Definition } \\
\hline $\begin{array}{c}\text { 1. Teamwork and } \\
\text { cooperation }\end{array}$ & $\begin{array}{l}\text { The individual perceives teamwork as an } \\
\text { effective way to achieve the tasks assigned to } \\
\text { the group, adds value to the work of the team, } \\
\text { effectively interacts with team members }\end{array}$ \\
\hline 2. Leadership & The individual has a clear vision of the result, \\
\hline
\end{tabular}




\begin{tabular}{|c|c|}
\hline & $\begin{array}{l}\text { ways to achieve it, makes decisions about the } \\
\text { direction of movement, inspires team members } \\
\text { to work effectively, takes responsibility for the } \\
\text { final result }\end{array}$ \\
\hline $\begin{array}{l}\text { 3. Ability to design and } \\
\text { manage projects }\end{array}$ & $\begin{array}{l}\text { The individual understands how to achieve the } \\
\text { desired result, offers (develops) and launches } \\
\text { algorithms and procedures for solving specific } \\
\text { problems, controls the quality and timing of } \\
\text { their implementation }\end{array}$ \\
\hline 4. Creativity & $\begin{array}{l}\text { The individual demonstrates a creative, } \\
\text { conceptual, non-standard approach to } \\
\text { achieving the goals set for him, knows how to } \\
\text { "come up with ideas" and has a positive } \\
\text { attitude to the new }\end{array}$ \\
\hline $\begin{array}{l}\text { 5. Ability to work } \\
\text { autonomously }\end{array}$ & $\begin{array}{l}\text { The individual is able to work independently } \\
\text { and responsibly, both in terms of motivation, } \\
\text { incentives ("emotional support") and providing } \\
\text { oneself with the necessary resources for work } \\
\text { and information, and in terms of (minimal) } \\
\text { external control }\end{array}$ \\
\hline $\begin{array}{l}\text { 6. Ability to be critical } \\
\text { and self-critical }\end{array}$ & $\begin{array}{l}\text { The individual considers content criticism in } \\
\text { his address and towards others as an important } \\
\text { and necessary condition for achieving a result, } \\
\text { does not perceive criticism as "something } \\
\text { personal", knows how to give a critical } \\
\text { assessment of his activities, corrects his actions } \\
\text { on the basis of criticism, and expects the same } \\
\text { from others }\end{array}$ \\
\hline $\begin{array}{l}\text { 7. Interpersonal and } \\
\text { interactional skills }\end{array}$ & $\begin{array}{l}\text { The individual attaches great importance to } \\
\text { communication with colleagues (and so on), as } \\
\text { a means of improving overall efficiency, } \\
\text { considers informal interaction practices as an } \\
\text { important complement to formal rules and } \\
\text { procedures, takes into account the hidden } \\
\text { interests and behavior patterns of others }\end{array}$ \\
\hline $\begin{array}{l}\text { 8. Ability to resolve } \\
\text { conflicts and negotiate }\end{array}$ & $\begin{array}{l}\text { The individual is able and willing to act as a } \\
\text { mediator in interpersonal and inter-institutional } \\
\text { communications, including negotiating and / or } \\
\text { facilitating conflict resolution }\end{array}$ \\
\hline $\begin{array}{l}\text { 9. Ability to plan and } \\
\text { allocate your time }\end{array}$ & $\begin{array}{l}\text { The individual views time as a valuable } \\
\text { resource, and the timing of performance of } \\
\text { works - as a value, significant for the overall } \\
\text { effectiveness of the activity; the sequence of } \\
\text { steps, the schedule of their implementation, } \\
\text { controls their compliance, seeks ways to } \\
\text { optimize the use of time }\end{array}$ \\
\hline $\begin{array}{l}\text { 10. Ability to focus on } \\
\text { quality }\end{array}$ & $\begin{array}{l}\text { The individual considers the quality of work as } \\
\text { a value that is significant for overall } \\
\text { performance; is a sequence of steps and means } \\
\text { of monitoring the level of quality and } \\
\text { compliance with standards (their own or preset } \\
\text { from outside), looking for ways to improve } \\
\text { quality }\end{array}$ \\
\hline $\begin{array}{l}\text { 11. Ability to focus on } \\
\text { results }\end{array}$ & $\begin{array}{l}\text { The individual considers obtaining the planned } \\
\text { result of the work as an independent value, } \\
\text { significant for the overall effectiveness of the } \\
\text { activity; makes a sequence of steps and } \\
\text { controls to achieve the agreed result, seeks } \\
\text { ways to improve efficiency }\end{array}$ \\
\hline $\begin{array}{l}\text { 12. Ability to search for, } \\
\text { process and analyze } \\
\text { information from a } \\
\text { variety of sources }\end{array}$ & $\begin{array}{l}\text { The individual understands the value of } \\
\text { information for the overall effectiveness of } \\
\text { their activities, can search for information, } \\
\text { summarize and systematize it, analyze various } \\
\text { sources, verify information }\end{array}$ \\
\hline $\begin{array}{l}\text { 13. Ability to analytical } \\
\text { (system) thinking, } \\
\text { analysis and synthesis }\end{array}$ & $\begin{array}{l}\text { The individual is capable of logical thinking, } \\
\text { deep reflection of working situations, the } \\
\text { identification of cause and effect relationships, } \\
\text { the structuring and systematization of the } \\
\text { components of the problem, the comparison of } \\
\text { various factors and aspects, the rational } \\
\text { arrangement of priorities }\end{array}$ \\
\hline
\end{tabular}

\begin{tabular}{|c|l|}
\hline $\begin{array}{c}\text { 14. Understanding and } \\
\text { respect for the diversity } \\
\text { and multiculturalism of } \\
\text { society }\end{array}$ & $\begin{array}{l}\text { The individual is aware of the importance of } \\
\text { diversity and multiculturalism of society both } \\
\text { from the moral and ethical point of view, and } \\
\text { from the position of beneficial influence on the } \\
\text { institutional environment in which the } \\
\text { individual exists and conducts his activities }\end{array}$ \\
\hline 15. Client orientation & $\begin{array}{l}\text { The individual considers the "client" request } \\
\text { both from within the organization / team, and } \\
\text { from the outside, as a priority of its activity, } \\
\text { considers its effectiveness and effectiveness } \\
\text { through the prism of customer satisfaction, } \\
\text { understands and knows how to identify the } \\
\text { hidden needs and motivations of the client, } \\
\text { knows how to build relationships with it }\end{array}$ \\
\hline
\end{tabular}

The values of competencies were calculated as weighted sums of indicators included in their composition. Weights were obtained on the basis of peer review, carried out using the method of pairwise comparison of indicators and the subsequent division of indicators into three groups (the most important, relatively important, least important for this competence), and assigning them the same weights within the same group. Indicators and competencies were considered in the interval $[0 ; 1]$.

The research method implied the identification of comparatively less developed (scarce) competencies and comparatively more developed competencies both in general for all the universities studied and for individual higher education institutions, both for students of individual courses and for their entirety, both depending on gender, and from the direction of training.

For the location of the research institutions in the space of competences and the positioning of each particular institution in it, factor analysis was carried out based on 12 competences ${ }^{1}$ using the method of principal components (using rotation by the Varimax method) 2 components were singled out explaining $77 \%$ of the variance.

The component "Independent work, leadership" includes the following competencies:

\section{Leadership}

3. Ability to design and manage projects

5. Ability to work independently

6. Ability to be critical and self-critical

9. Ability to plan and allocate your time

11. Ability to focus on results

12. Ability to search for, process and analyze

information from different sources

13. Ability to analytical (system) thinking, analysis and synthesis

The component "Communicative Skills" includes the following competences:

1. Teamwork and cooperation

7. Interpersonal and interactional skills

14. Understanding and respect for the diversity and multiculturalism of society

15. Client orientation

The main results of the study are as follows.

1 Due to the simultaneous high correlation with both components, competences were not involved in the construction: 4 . Creativity, 8 . Ability to resolve conflicts and negotiate, 10 . Ability to focus on quality. 
In general, for all universities, the first-year students' communication skills of the 2015 set are more developed than in the first year of the 2016 recruitment.

For comparison, in general, NovSU students of the 2016 recruitment have the same set of competencies associated with independent work and leadership and with communication skills. Against the background of the other universities in the sample of competence, NovSU students are at the level of the average for the sample.

When comparing the freshmen of NovSU of the 2015 and 2016 recruitment, the set revealed differences in communicative skills and in the skills of independent work. The first year students of NovSU in 2016 have a less developed set of communicative skills in comparison with the first year of the recruitment in 2015 and have more developed skills of independent work and leadership.

When analyzing the dynamics of development of competences, the students of NovSU from the 3rd to the 4th year showed an improvement in communication skills and improved skills of independent work and leadership. Thirdyear students have self-study and leadership skills are relatively more developed than communication skills. By the 4th year, the level of competence development of both components is equalized.

In general, in the universities under study, the first-year students recruited in 2016 have a relatively more developed "Understanding and respect for the diversity and multiculturalism of society," and "Ability to focus on quality". The competences "Ability to work independently", and also "Ability to analytical (system) thinking, analysis and synthesis" are comparatively less developed (based on data of 2016 in 26 universities).

Freshmen of 2016 are on average "weaker" in terms of general cultural competencies than the first-year students of 2015. In particular, in terms of the competencies "Teamwork and cooperation", "Leadership", "Ability to develop projects and manage them", "Ability to plan and allocate their time", "Ability to focus on quality ", "Understanding and respect for the diversity and multicultural society", "Client Orientation "(based on 2015 and 2016 data for 18 universities).

The fourth-year students have comparatively more developed competences "Understanding and respect for diversity and multicultural society", as well as "Ability to focus on results". The competence "The ability to search for, process and analyze information from different sources" is comparatively less developed, as well as the "Ability to work independently" (based on data of 2016 in 9 universities).

In the first year there are significant differences in the level of development of certain competences among boys and girls. The boys have relatively better developed competences "Ability to be critical and self-critical", "Ability to resolve conflicts and negotiate", "Ability to analytical (system) thinking, analysis, synthesis". The girls have comparatively better developed competences "Teamwork and cooperation", "Aiming to focus on quality", "Understanding and respect for diversity and multiculturalism of society", "Client orientation".
By the fourth year, the differences in the level of development of general cultural competencies among boys and girls are equalized. However, girls still have better competencies "Aiming to focus on quality", "Understanding and respect for diversity and multiculturalism of society", "Client orientation".

The results of the research carried out by the Institute of National Projects jointly with other participants have found the development of universal competencies (UC) of federal educational standards in all areas and specialties of training. At the moment, eight universal competencies presented in educational standards are grouped into seven categories (groups):

1) systemic critical thinking. This group corresponds to the universal competence UC-1 - to be able to search, critically analyze and synthesize information, apply a systematic approach to solve assigned problems;

2) development and implementation of projects. This group corresponds to the universal competence UC-2 - to be able to determine the range of tasks within the stated goal, to implement and choose the best ways to solve them, based on existing legal norms, available resources and restrictions;

3 ) teamwork and leadership. It uses the competence UC-3 - to be able to carry out social interaction and realize the work in a team;

4) communication. For this group, the competence UC4 has been developed - to be able to carry out business communication in oral and written forms in the state language of the Russian Federation and in foreign language(s);

$5)$ intercultural interaction. This group corresponds to the universal competence UK-5 - to be able to perceive the intercultural diversity of society in the socio-historical, ethical and philosophical contexts;

6) self-organization and self-development (including health preservation). For this group, two universal competencies have been developed: UC-6 - to be able to manage the time, build and implement a self-development path based on the principles of lifelong education; UC-7 - to be able to maintain a proper level of physical fitness to ensure full-fledged social and professional activity);

7) life safety. This group corresponds to the universal competence UC- 8 - to be able to create and maintain safe living conditions, including the event of emergencies.

As can be seen from the presented characteristics of universal competencies, the process of implementing the competence approach in education is complex and far from complete.

Defining general professional competencies is also not an easy task, but the main difficulty lies in the formulation of professional competencies, because they must rely on professional standards, which also undergo the process of development and approval. Unfortunately, at the moment, professional standards are far from being developed for all types of activities. It "slows down" the development of educational standards, professional competencies and, consequently, the very implementation of the competence approach. There is a gap between educational and professional 
standards and the real state and development trends of the economy. This asymmetry, due, inter alia, to the digital transformation of the economy, requires the introduction of exclusively innovative approaches to the educational process.

The changes occurring in the world and in Russia in the field of education goals, correlated with the global task of entering the new digital world and its productive adaptation in this world, make it necessary to raise the issue of providing education with a more fully personal and socially integrated result, since the required competencies often do not have time for the dynamics of the technological environment.

Digital economy is a term used to describe the development prospects of any modern state. This is a completely new business model that unites the physical and digital worlds. The adoption of state programs, the transfer of various economic, political, educational and other social processes to the virtual environment should bring the country closer to a complete transformation of habitual economic ties and business models that existed earlier, and change the attitude of ordinary citizens to the use of digital technologies in everyday life. The decisive influence of information technology today is conditioned by:

- appearance of broadband Internet access;

- availability of computers, tablets and smartphones;

- increased penetration of social networks;

- spread of digital marketing and e-technologies;

- appearance of functional platforms for distance learning;

- development of online learning technologies and opportunities for webinars;

The change in the consciousness of a large part of the population should be the basis for the digital transformation, so necessary for the development and implementation of breakthrough technologies, increasing labor productivity and competitiveness of firms and regions, reducing consumption of resources, raising the level and quality of life. Modern man is an active Internet user. And this happens not only due to subjective reasons, such as meeting the needs for communication and self-realization (for example, through communication in social networks), but also objective ones as far as most of the processes have already been transferred to the virtual environment (e-commerce, e-government, management water, energy, fuel resources, distance learning, etc.). In connection with these circumstances, new business opportunities, creation of innovative products, and, consequently, the need for a high rate of creation and mastering of new knowledge is growing [23]. First and foremost, it is required to provide future specialists with the necessary competences and skills in the digital environment. The list of categories of specialists is quite extensive, starting with IT professionals, business executives and entrepreneurs, and ending with ordinary professions of doctors, teachers, social workers. A separate position in this list is occupied by employees of the state apparatus - officials of various levels, different specializations, different spheres of activity and institutions.
In Russia, this task should be solved by the potential of higher education system, which will respond to external challenges and will be reconstructed itself in form and content. The possibilities of higher education, as a form of reproduction of human capital for the digital economy, largely depend on innovative approaches to learning. The new economy is based on the recognition of the primary importance of the intellect, ideas, and knowledge that are formed in the system of higher education, and the level of training and quality of the workforce directly depends on how flexibly and accurately this system responds to new challenges and needs of the digital society forming the necessary competences of the employee. "Creative human capital" potential, success achievement in any sphere implies spatial imagination, non-standard thinking, initiative, leadership, a broad horizon of vision problems [24].

Digital technologies and the rhythm of business activity continue to accelerate, which means that no knowledge and skills acquired once in an educational institution can guarantee a permanently stable "life cycle" and decent earnings. The set of competencies acquired in the university begins to burn out for several years, and one must always be ready to radically change the profession or the terms of reference, if circumstances require that.

Russia can not lag behind in mastering new technologies and allow the proliferation of a mass of lowskilled workers who have not found a use for post-industrial information platforms. In this regard, it is extremely important to take care of changing approaches to education. The changes that are taking place raise the issue of digital transformation of the Russian higher education system.

The innovative strategy of higher education predetermines the paradigmatic approach to vocational competence education, the movement from subject-content learning to synergetic pedagogy, to the formation of a worldviewable type of general methodological cognition [25], the personality model of learners and the assimilation of new knowledge. Innovative changes in higher education should ensure the implementation of functional approaches to the quality of training of modern professionals:

- accelerator approach related to providing such a level of knowledge of people, which corresponds to the necessary production and social competence;

- adaptive-amortization approach, leveling gap of generations on the educational level, awareness and value orientations in the face of changing requirements of the digital socio-economic environment;

- compensatory and corrective approach, ensuring the overall cultural development of the individual, its creative potential, satisfaction of the intellectual needs of the information society.

The innovative potential of the digital transformation of the Russian higher education system has a vector of focus on the formation of an adaptable competent and developed personality, a rationally thinking business person, ready to live in a post-industrial era of market relations. The integration model of an adapted competent-developed personality in the 
system of professional-educational public relations is presented in Figure 1.

Thus, for the purpose of practical implementation of the presented model, it is necessary to form a new propaedeutic system of integrated education, which includes additional didactic principles and pedagogical means that ensure intelligibility, understandability, and accessibility of socio-economic and information-technological knowledge [26]. Propaedeutics implies further convergence of didactic elements of business education and IT-technologies as conditions for developing approaches to a deeper understanding of modern socio-economic practices.

Orientation to new needs of society leads to a different level of training future specialists, to development of their knowledge and competencies that meet the requirements of the digital economy. However, this restructuring is extremely slow: the academic disciplines that form specified competences of the new economy are not yet introduced in all Russian universities. At the same time, foreign universities are successfully training in such disciplines as "Digital Business", "Digital Corporate Management", "Financial Cyber Security", "Digital and Electronic Universal Banking Technologies", "Integrated Electronic Banking and Digital Financial Instruments (crypto-currency, program mining, etc.)". Some of these courses can also develop into independent areas of master's or professional training. The authors consider the potential for the development of the Russian higher education system, not only as such, but also in the context of effective training of high-level specialists, a level that meets the requirements of the future.

At the same time, there are successful domestic developments provided with the accumulated intellectual capital of domestic specialists in this direction. This is, for example, Coursera, the platform "Open Education", Skolkovo Institute of Science and Technology (SkTech), University of the National Technology Initiative (NTI) "20.35". The latter is a university that provides professional development of a person in the digital economy. It is focused on training leaders of companies, participants of the National Technological Initiative (NTI) and specialists working in new global markets. Within the framework of training, the university offers to "acquire" the following competencies, conventionally divided into three categories:

1) key competencies: communication, cooperation, decision-making, problem solving, etc.;

2) personal qualities: personal and social responsibility, awareness, leadership, productivity, ability to learn, selfregulation, etc.;

3) elements of new literacy: legal, technical, entrepreneurial, scientific, economic and financial, intercultural and other kinds of literacy.

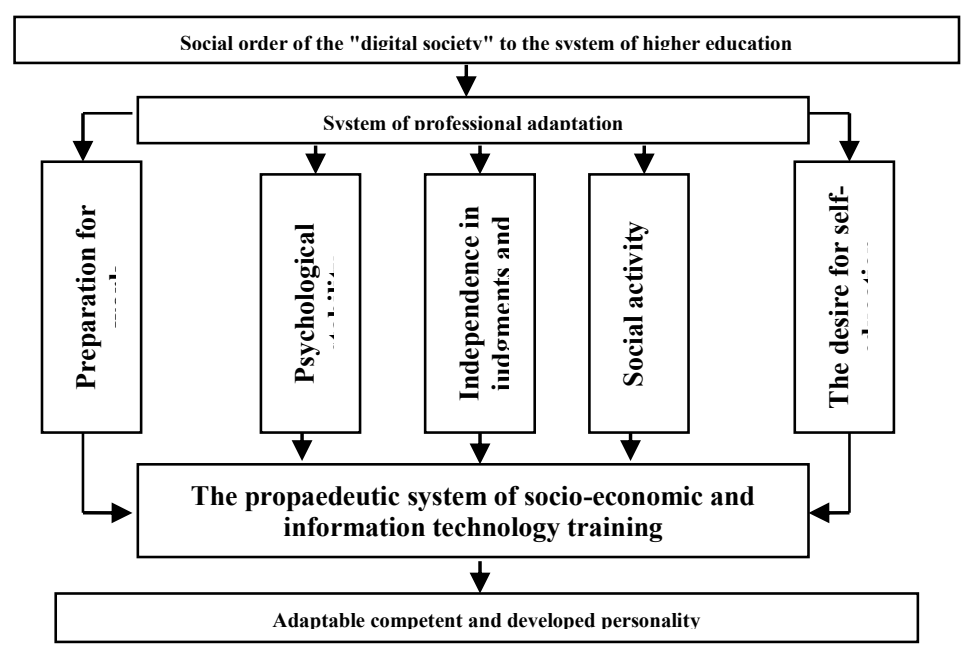

Fig.1. Integration model of an adaptable competent and developed personality

Personal educational trajectories for each participant allow to build training according to individual needs and to receive a specialist-leader in business, technological innovations or capable of effectively managing changes. The educational process consists of several tracks: a track of project training, a track of forming technological competences, an individual track of basic disciplines, a track of interdisciplinary basic courses of the university. This approach is fundamentally different from the framework conditions set by the state educational standards, however, in order to obtain the desired result, a permanent adjustment of the personal educational trajectory is necessary in accordance with the emerging needs and the level of mastering the competences which allows us to do the program of this university.

\section{CONCLUSION}

Thus, the seemingly independent trends in the transformation of education and the economy, which began more than ten years ago, are now increasingly interdependent, forming a synthesis of innovative changes in education and the economy in the digital transformation of the world. And this not only does not contradict the concept of lifelong learning (Life Long Learning), but, on the contrary, supplements and concretizes it, making the process of continuous personality formation interlinked with the main trends in the development of the economy and society, i.e. willingness to live in a dynamic and uncertain future.

The coherence of educational technologies and the demands of the modern labor market will fully reveal the potential of human capital in the transition to a qualitatively new stage in the development of society, in which Digital Skills and Soft Skills are added to the professional competencies of the employee, the so-called 21 st century skills and a new type of thinking.

Adopting the fact that education has ceased to be unchanged, once established and not requiring a reorganization of the institution of society, provides 
opportunities for approbation and development of innovative solutions, including the integrated model of the adaptable competent and developed personality presented in the work. This personality is the immediate productive force and the fundamental basis of the new digital economy.

\section{REFERENCES}

[1] Trifonov V. A., Shabashev V. A., Verzhitsky D. G. The problems of developing the ecological market of the region // Applied Mechanics and Materials. - 2014 - Vol. 682. - p. 591-595; doi: 10.4028/www.scientific.net/AMM.682.591.

[2] Mitchell D., Nielsen S. Internationalization and globalization in higher education // Globalization - Education and Management Agendas. - Rijeka: InTech, 2012. - P. 13-34. doi: http://dx.doi.org/10.5772/48702.

[3] Zhafyarov A. Zh. Technology of implementing the competencebased approach within the school course of Mathematics. Novosibirsk State Pedagogical University Bulletin, 2017, no. 2, pp. 71-84. doi: http://dx.doi.org/10.15293/2226-3365.1702.05.

[4] Feast V., Collyer-Braham S., Bretag T. Global Experience: the development and preliminary evaluation of a programme designed to enhance students' global engagement // Innovations in Education and Teaching International. - 2011. - Volume 48, pp 239-250; doi:10.1080/14703297.2011.593701.

[5] Tearle P., Dillon P. The Development and Evaluation of a Multimedia Resource to Support ICT Training: Design Issues, Training Processes and User Experiences // Innovations in Education and Teaching International. - 2011. - Volume 38, pp 8-18; doi: $10.1080 / 147032901300002819$.

[6] Selwyn N., Williams S., Gorard St. 'E-stablishing a Learning Society': the Use of the Internet to Attract Adults to Lifelong Learning in Wales // Innovations in Education and Teaching International. - 2011. - Volume 38, pp 205-219; doi: $10.1080 / 14703290110052302$.

[7] Nian-Shing Chen, Hsiu-Chia Ko, Kinshuk, Taiyu Lin. A model for synchronous learning using the Internet // Innovations in Education and Teaching International. - 2005. - Volume 42, pp 181-194; doi: 10.1080/14703290500062599.

[8] Loshchilova M. A., Lizunkov V. G., Zavjyalova A. V. Professional Training of Bachelors in Mechanical Engineering, Based on Networking Resources // Procedia - Social and Behavioral Sciences. - 2015. - Vol. 206. - P. 399-405. doi: https://dx.doi.org/10.1016/j.sbspro.2015.10.073.

[9] Kazimova D. A., Shraimanova G. S., Abdulmanova D. I., Esmagambetova D. B.Comprehensive Aspects in Management Competence of Father Pedagogues in Vocational Education System // European Researcher. - 2014. - Vol. 78, № 7-1. - P. 1278-1285. doi: http://dx.doi.org/10.13187/issn.2219-8229.

[10] Ducrotoy J.-P. Higher Education in Coastal Sciences and Management: Establishing a Partnership Between Education and Industry // Innovations in Education and Teaching International. 2001. - Volume 38, pp 239-250; doi: 10.1080/14703290110052311.

[11] José Antonio Cavero Rubio, Javier Reig Mullor, Agustín Pérez Martín. Studies in business administration in the European higher education area: a comparative analysis in Europe // Innovations in Education and Teaching International. - 2014. - Volume 52, pp 112; doi:10.1080/14703297.2014.928228.

[12] Lizunkov V. G., Marchuk V. I., Podzorova E. A. Identification of Criteria, Features and Levels of Economic and Managerial Competencies Development for Bachelors in Mechanical Engineering // Procedia - Social and Behavioral Sciences. - 2015. $\begin{array}{lllll}\text { Vol. } 206 . & - & \text { P. 388-393. doi: }\end{array}$ https://dx.doi.org/10.1016/j.sbspro.2015.10.071.
[13] Unger M., Polt W. (2017) The Knowledge Triangle between Research, Education and Innovation - A Conceptual Discussion. Foresight and STI Governance, vol. 11, no 2, pp. 10-26. doi: 10.17323/2500-2597.2017.2.10.26.

[14] Shamsi A. (2017) The Relationship between Knowledge Management and Managerial Skills: The Role of Creative Thinking. Foresight and STI Governance, vol. 11, no 4, pp. 44-51. doi: 10.17323/2500-2597.2017.4.44.51.

[15] Ahmed H. O. K. Flipped learning as a new educational paradigm: an analytical critical study // European Scientific Journal. - 2016. - Vol. 12, № $10 . \quad-\quad$ P. 417-444. doi: http://dx.doi.org/10.19044/esj.2016.v12n10p417.

[16] West D., Thompson S. Mobile knowledge: driving a paradigm shift // Journal of Applied Research in Higher Education. - 2015. - Vol. 7, Issue 1. - P. 43-54. doi: http://dx.doi.org/10.1108/JARHE-02-20140021.

[17] Davidson C. N. Why higher education demands a paradigm shift // Public Culture. - 2014. - Vol. 26, № 1 72. - P. 3-11. doi: http://dx.doi.org/10.1215/08992363-2346313.

[18] Ferreira R., Lizunkov V. G., Politsinskaya E. V. Formation of entrepreneurial competencies of university graduates in conditions of transition to the universities of the third generation, Novosibirsk State Pedagogical University Bulletin, 2017, No.6, pp. 195-211. doi: http://dx.doi.org/10.15293/2226-3365.1706.12.

[19] Kostin I., Chionova N., Teleshova I, Echenique V, Ulyanova M., Kudryashova T., Marico V., Markar'yan Yu., Moshkova L., Parakhina V., Vostrikova E. Reference Points for the Design and Delivery of Degree Programmes in Management. Materials of Tuning Russia project 511135-TEMPUS-I-2010-1-ES-TEMPUSJPCR. - Bilbao: Deusto University Press, 2013. -60 p.

[20] Teleshova I, Echenique V, Ulyanova M., Kostin I., Chionova N., Kudryashova T., Marico V., Markar'yan Yu., Moshkova L., Parakhina V., Vostrikova E. Reference Points for the Design and Delivery of Degree Programmes in Economics. Materials of Tuning Russia project 511135-TEMPUS-I-2010-1-ES-TEMPUS-JPCR. Bilbao: Deusto University Press, 2013. - 72 p.

[21] Andreev V., Fomicheva Zh., Kotova N., Kryukova N., Murugova E., Zhukova E. Reference Points for the Design and Delivery of Degree Programmes in Foreign Languages. Materials of Tuning Russia project 511135-TEMPUS-I-2010-1-ES-TEMPUS-JPCR. - Bilbao: Deusto University Press, 2013. -66 p.

[22] Zabotkina V., Kabakhidze E., Kotova N., Krakovich V., Kruglyakova V., Murugova E., Reingold N., Sudakova O., Zhukova E. Reference Points for the Design and Delivery of Degree Programmes in Interpreting and Translation. Materials of Tuning Russia project 511135-TEMPUS-I-2010-1-ES-TEMPUS-JPCR. Bilbao: Deusto University Press, 2013. - 70 p.

[23] Decree of the President of the Russian Federation of 01.12.2016 No. 642 "On the Strategy for Scientific and Technological Development of the Russian Federation" http://www.kremlin.ru/acts/bank/41449 (in Russian).

[24] Tuljchinsky G.L. Digital transformation of education: challenges for higher education // Philosophskie nauki. 2017. No 6. P. 121-136 (in Russian).

[25] Lisitsky D. V., Osipov A. G., Kicheev V. G., Savinykh V. N., Makarenko N. N. Dynamics of Higher Education Paradigms in Russia (from the end of the 19th century to the beginning of the 21st century) // Novosibirsk State Pedagogical University Bulletin, 2017, No.3, pp.157-175. doi: http://dx.doi.org/10.15293/22263365.1703.10.

[26] Vetkina A. V. Realization of the principles of economic hermeneutics in the system of professional adaptation // Vestnik of Yaroslav-the-Wise Novgorod State University, 2015. No 4-2(87). P. 68-72 (in Russian). 